\title{
The pathogenesis of keratoconus
}

\begin{abstract}
Keratoconus $(\mathrm{KC})$ is a common degenerative condition that frequently results in visual loss with an onset typically in early adulthood. It is the single most common reason for keratoplasty in the developed world. The cause and underlying pathological mechanism are unknown, but both environmental and genetic factors are thought to contribute to the development of the disease. Various strategies have been employed to address the gap in our understanding of this complex disease, with the expectation that over time more sophisticated therapies will be developed. In this review we summarise our current knowledge of the aetiology and risk factors associated with $\mathrm{KC}$.
\end{abstract}

Eye (2014) 28, 189-195; doi:10.1038/eye.2013.278; published online 20 December 2013

Keywords: keratoconus; cornea; molecular genetics

\section{Introduction}

Keratoconus (KC, OMIM 14830) is bilateral progressive thinning and ectasia of the cornea that results in blurred vision from irregular astigmatism. The changes may be markedly asymmetric and in advanced disease axial corneal scarring can develop that further reduces vision. A number of different phenotypes are recognised such as predominant axial corneal thinning (apex cone), inferior corneal thinning (dropped cone, pellucid marginal degeneration), or generalised corneal thinning (keratoglobus), but it is unclear whether these are variants of $\mathrm{KC}$ or distinct conditions. ${ }^{1,2}$ Similarly, it is not known whether a generalised thinning of the cornea without ectasia, or regular astigmatism are risk factors for the development of $\mathrm{KC}$, a partial expression of the disease, or unrelated phenomena.

After the onset of $\mathrm{KC}$ various environmental effects such as inflammation, degeneration or
AE Davidson ${ }^{1}$, S Hayes $^{2}$, AJ Hardcastle ${ }^{1}$ and SJ Tuft ${ }^{1,3}$

scarring cause secondary changes that modify the corneal tissue. Each step of this process has been examined with regard to the pathogenesis of $\mathrm{KC}$, but as with many complex diseases, distinguishing between association, cause and effect is problematic and extremely challenging. ${ }^{3}$ Thus, despite a great deal of research, the aetiology of $\mathrm{KC}$ is still poorly understood. For KC the currently recognised environmental influences include contact lens wear, chronic eye rubbing and allergic eye disease. ${ }^{2}$ Importantly, although the development of disease involves complex interactions between genetic and environmental factors, ${ }^{4}$ their relative contributions to disease are currently unknown and likely to be variable. Research strategies to unravel KC pathogenesis include histochemistry, biomechanics, enzymology, proteomics, and molecular genetics. These studies have certainly enhanced our understanding, but are confounded by the fact that research efforts have largely focussed on patients with relatively advanced disease, where it can be difficult to distinguish primary disease mechanisms from secondary inflammatory or degenerative effects, and by the possibility that the clinical appearance of $\mathrm{KC}$ can include phenocopies that derive from a number of unrelated environmental or genetic effects. KC may thus be the final common pathway for many different pathological processes. Here, we review the data generated to dissect the pathogenesis of $\mathrm{KC}$ in an effort to reconcile the knowledge gained so far.

\section{Structure and proteomics}

One of the first theories for the pathogenesis of $\mathrm{KC}$ was that the primary insult was an epithelial abnormality, resulting in the release of proteolytic enzymes that degrade stromal collagen to thin and weaken the cornea. ${ }^{5}$ Involvement of epithelial cells in the disease process is supported by the observation of structural irregularities in the epithelium
${ }^{1}$ Department of Ocular Biology and Therapeutics, UCL Institute of Ophthalmology, London, UK

${ }^{2}$ Cardiff Centre for Vision Sciences, College of Biomedical and Life Sciences, Cardiff University, Cardiff, UK

${ }^{3}$ Corneal Service, Moorfields Eye Hospital NHS Foundation Trust, London, UK

Correspondence: SJ Tuft, Cornea \& External Eye Disease, Moorfields Eye Hospital NHS Foundation Trust, 162 City Road, London EC1V 2PD, UK. Tel: +44 (0)20 7566 2375; Fax: +44 (0)20 7566 2019; E-mail: s.tuft@btinternet.com

Received: 18 October 2013 Accepted: 20 November 2013

Published online: 20 December 2013 
(blebbing and degeneration) that appear to progress with the disease. ${ }^{6}$ However, with light microscopy there is additional evidence of major structural changes in other corneal layers, including breaks in Bowman's layer and stromal thinning. ${ }^{5,7}$ The minor changes of cellular pleomorphism of the endothelium are most likely secondary to contact lens induced hypoxia or mechanical stress. ${ }^{8}$

There is conflicting evidence regarding biochemical abnormalities in KC, with reports of increased, ${ }^{9}$ decreased, ${ }^{10}$ or normal levels ${ }^{11}$ of proteoglycans. Examination of the proteome of $\mathrm{KC}$ tissue has confirmed that, compared with normal cornea, there is upregulation of decorin and keratocan. ${ }^{12-14}$ Keratan sulphate proteoglycan appears to be structurally altered in $\mathrm{KC}$ corneas, perhaps containing fewer keratan sulphate chains. ${ }^{15}$ The majority of studies agree that in $\mathrm{KC}$ the stromal collagen content is decreased ${ }^{9,10}$ but that there are no dramatic changes in either the distribution of the various collagen types ${ }^{16-18}$ or in the cross-linking pattern ${ }^{19}$ and molecular arrangement of the collagen within the stroma. ${ }^{9,20}$ The exception is the altered distribution of collagen type III in scarred regions of KC tissue. ${ }^{18}$

Several studies have investigated the KC-associated proteome. Examination of the tears or corneal tissues from patients with $\mathrm{KC}$ has identified differential expression of proteins compared with controls. These studies provide additional clues about the pathology of the disease as well as identifying potential targets for treatment. The expression of a range of proteins, including cytokines and enzymes, is altered in KC when compared with normal controls, suggesting the involvement of apoptosis and scarring in the disease process. However, it is unclear whether the pathways are modified as a primary or secondary phenomenon. Examination of tear fluid indicated that there are $>1500$ proteins in the tears, ${ }^{21}$ and that inflammation has a role in the pathogenesis of KC. ${ }^{22,23}$ Proteomic studies of the KC epithelial and stromal layers have demonstrated that structural remodelling and metabolic stress occur in both layers. Many extracellular matrix proteoglycans and proteins involved in proliferation, growth and migration were found to be downregulated in $\mathrm{KC}$ epithelium and stroma, and oxidative stress was evident. ${ }^{24,25}$

\section{Biomechanics}

The corneal tissue in $\mathrm{KC}$ is less rigid than normal tissue ${ }^{26}$ and an increased axial length suggests a relationship with myopia. ${ }^{27}$ The stroma is predominantly formed of water and type I collagen. The collagen fibrils lie parallel to each other within lamellae, which are themselves stacked parallel to the surface of the cornea. Stromal thinning, a hallmark of $\mathrm{KC}$, is caused by a reduction in the number of lamellae within the affected region ${ }^{28}$ rather than compaction of collagen fibrils within individual lamellae, ${ }^{29}$ but the mechanism by which the thinning occurs is uncertain. Although stromal thinning in $\mathrm{KC}$ has been attributed to collagen degradation by proteolytic enzymes ${ }^{30,31}$ or decreased levels of proteinase inhibitors, ${ }^{32}$ it has also been proposed that collagen is not lost but simply redistributed within the cornea by slippage between the lamellae. ${ }^{33}$ This latter mechanism is supported by the observation of reduced inter-lamellar adhesion, ${ }^{34}$ lamellar interlacing in the apex of $\mathrm{KC}$ corneas $^{35,36}$ and a reduced number of lamellar insertions into Bowman's layer. ${ }^{35} \mathrm{X}$-ray diffraction studies provide some of the strongest evidence to support this theory. In the deeper stromal layers of the healthy cornea the collagen is predominantly aligned in the superiorinferior and nasal-temporal orthogonal directions. ${ }^{37,38}$ However, this arrangement was markedly altered in the apical region of advanced KC. ${ }^{19,39,40}$ These later studies also presented evidence of a redistribution of lamellae away from the apex of the cone and highlight a variability of collagen distribution patterns between individual cases. ${ }^{19,39}$ On the basis of these findings, Meek et al proposed that the loss of structural integrity in the $\mathrm{KC}$ cornea was caused by the presence of abnormal keratocytes and matrix proteins ${ }^{15,31}$ and upregulated proteolysis triggered an unravelling of lamellae along their length and from their anchors at the limbus, with an opening of the lamellar bifurcations. This theory is supported by observations following riboflavin/UVA collagen cross-linking, where the proposed cross-linkage of the tissue increases both the resistance of the stroma to enzymatic digestion and the cohesiveness between collagen fibrils and the non-collagenous matrix. ${ }^{41}$ The molecular basis of the abnormality in the matrix collagen interaction has yet to be determined.

\section{Genetics}

The reported prevalence of $\mathrm{KC}$ is highly variable ranging from 2340 per 100000 in Israel $^{42}$ to $0.2-0.4$ per 100000 in Russia. ${ }^{43}$ This large discrepancy may in part reflect differences in diagnostic criteria and the age group studied, however such variability is also likely to reflect the differences in genetic variation in such populations. In the UK, prevalence of $\mathrm{KC}$ has been estimated to be 4.4-7.5 times greater for Asians compared with white Caucasians. ${ }^{44,45}$ Although the majority of cases of $\mathrm{KC}$ are sporadic, reports of familial cases of $\mathrm{KC}$ are also common and aggregation of the disease in families is often observed. ${ }^{46}$ The prevalence of $\mathrm{KC}$ in first degree relatives of index cases has been estimated to be $3.34 \%$, notably higher than that in the general population. ${ }^{47}$ 
Concordance is also high among monozygotic twins and a greater similarity of phenotype is observed in monozygotic twin pairs implying that genetic factors are likely to have a key role in the disease phenotype. ${ }^{48}$

$\mathrm{KC}$ has been associated with a wide range of systemic and ocular conditions, for example Leber congenital amaurosis, ${ }^{49}$ anterior polar cataract, ${ }^{50}$ Brittle cornea syndrome, ${ }^{51,52}$ and with a 10-300-fold higher prevalence in individuals with Down syndrome. ${ }^{53,54}$ Interestingly, individuals with connective tissue disorders such as Ehlers Danlos syndrome have a higher prevalence of KC. ${ }^{55,56}$ The caveat to these observations is that mutations in the causative genes have not been shown to be enriched or causative in isolated $\mathrm{KC}$ cases. Therefore, the relevance of the increased occurrence of $\mathrm{KC}$ in these genetic conditions has yet to be established. Genetic risk factors for $\mathrm{KC}$ have proven difficult to identify because of the complex nature of the condition. Several genetic approaches have been employed, including linkage studies in families with predominantly suspected dominant inheritance of $\mathrm{KC}$, candidate gene analysis in $\mathrm{KC}$ cohorts, and genome-wide association studies (GWAS) to identify risk loci. Candidate genes for $\mathrm{KC}$ have been considered primarily on the basis of their biological function. For example, the superoxide dismutase isoenzyme 1 encoded by SOD1 located on chromosome 21 was considered an attractive candidate gene because oxidative stress is hypothesised to have a role in the aetiology of $\mathrm{KC}^{57}$ and there is an increased prevalence of $\mathrm{KC}$ in patients with Down syndrome (trisomy 21)..$^{58}$ Despite the identification of an intronic deletion that segregated with $\mathrm{KC}$ in two small families, 58 this finding has not been replicated in additional cohorts, ${ }^{59,60}$ and it remains to be established whether variants in this gene are associated with KC. Similarly, other studies have investigated the transcription factor visual system homeobox 1 encoded by VSX1, a gene implicated in posterior polymorphous corneal dystrophy (PPCD), because these PPCD patients have localised steepening of the anterior cornea similar to KC. ${ }^{61}$ To date, more than $1500 \mathrm{KC}$ patients have been screened for VSX1 and potentially pathogenic mutations have been identified in less than $2 \%$ of cases suggesting that this gene does not have a major role in the molecular pathology of $\mathrm{KC} .{ }^{60,62-64}$ Other candidate genes screened in KC cohorts include TIMP3, ${ }^{65}$ TGFBI, $^{66,67} \mathrm{ZEB1}^{68}{ }^{68}$ FLG $^{69}$ and several collagen genes. ${ }^{46,70,71}$ Despite these efforts, potentially pathogenic variants have only been identified in a very small number of individuals with $\mathrm{KC}$.

Although large families with $\mathrm{KC}$ are very uncommon, several groups have described extended familial inheritance of $\mathrm{KC}$, the majority with an apparent dominant, or dominant partially penetrant inheritance pattern. In these familial cases, linkage analysis has been performed. This approach has proven to be powerful for other familial forms of complex disease such as myopia ${ }^{72}$ and systemic lupus erythematosus. ${ }^{73}$ To date, 17 distinct potential loci for $\mathrm{KC}$ are described, ${ }^{74}$ however, only three of these loci have been independently replicated, $5 q 21,75,765 q 32^{75,77}$ and 14q11.75,77 Collectively, these findings suggest that there is a high degree of genetic heterogeneity for $\mathrm{KC}$. Unfortunately, convincing $\mathrm{KC}$-associated genes have not been identified within these reported loci, with one notable exception; the identification of a potentially pathogenic variant in candidate gene DOCK9, segregating in a large dominant KC family of Ecuadorian origin. ${ }^{78}$ There are several reasons for this lack of identification of causative genes from linkage studies. Using conventional linkage strategies to understand complex diseases relies on the assumption that the condition is caused by a variant that has a large effect, and this may be an over-interpretation of familial aggregation of $\mathrm{KC}$ in many instances. ${ }^{79}$ The application of linkage analysis is also complicated by the possibility of phenocopies and reduced penetrance in any given KC pedigree. The inclusion of individuals with simple astigmatism, thin corneas without ectasia, or borderline (forme fruste) $\mathrm{KC}$ disease is also controversial. In addition, despite the typical age of $\mathrm{KC}$ onset in the second decade of life, onset has been reported over the age of 50 years ${ }^{80}$ making the classification of individuals as unaffected difficult. Furthermore, large families are required to obtain robust linkage and many of the studies performed to date have not identified regions of linkage with significant LOD scores. ${ }^{74}$ Finally, different loci and genes may be implicated in families of different ethnicities, confounding replication of the loci. Given these complexities, there is hope that progress will be made using recent advances in next-generation sequencing technologies. Time- and cost-effective strategies to sequence all genes in the defined locus, or the entire linked region, for genetic variants is now a realistic possibility and will undoubtedly facilitate progress to identify the genetic variant(s) segregating with disease in these extended families. ${ }^{81}$ Of particular relevance, linkage analysis in combination with nextgeneration sequencing identified a heterozygous mutation in mir-184 in two families with dominant congenital cataract associated with a corneal phenotype that in some cases was consistent with $\mathrm{KC} .^{50,82,83}$ To establish whether mutations in mir-184 were associated with $\mathrm{KC}$, mir-184 was subsequently screened in a cohort of $780 \mathrm{KC}$ patients. ${ }^{84}$ Rare variants were identified in two $(0.25 \%)$ patients, but the variants did not fully segregate with disease, suggesting that mir-184 variants are not a common cause of isolated $\mathrm{KC} .^{84}$

Genome-wide association studies (GWAS) are a powerful tool to identify common variants of relatively 
low effect as risk factors for complex disease. ${ }^{85}$ Several KC GWAS have been performed, but with relatively small numbers of patients. An early study that included three cohorts from Australia, USA and Northern Ireland implicated genetic variation at the HGF locus with KC susceptibility, although it did not reach genome-wide significance. ${ }^{86}$ A more recent KC GWAS case-control study for a Caucasian cohort from the USA identified a single-nucleotide polymorphism (SNP) near RAB3GAP1 as a potential susceptibility locus for $\mathrm{KC} .{ }^{87}$ Again the study did not reach genome-wide significance, but this finding has been replicated in an Australian Caucasian cohort. $^{88}$

Another approach is to test for association with endophenotypes of the disease, rather than a casecontrol study, or to combine these approaches. There has been much interest in defining loci associated with central corneal thickness (CCT), which is a highly heritable quantitative trait. ${ }^{89}$ Reduced CCT is a hallmark of $\mathrm{KC}$ and a risk factor for primary open-angle glaucoma. ${ }^{90}$ Recently, an elegant and extensive study described a meta-analysis of GWAS for CCT that included over 20000 Caucasian and Asian individuals. This study identified 16 new loci associated with CCT at genome-wide significance..$^{91}$ To investigate whether any CCT-associated loci identified also influence genetic susceptibility to $\mathrm{KC}$, the authors tested for association of these loci in a case-control study including 874 patients with KC. This meta-analysis identified six SNPs that were strongly associated with a risk of $\mathrm{KC}$, within or nearby the following genes/loci; FOXO1, FNDC3B, RXRA-COL5A1, MPDZ-NF1B, COL5A1, and ZNF469. Of the six significant loci, the SNP rs9938149 $160 \mathrm{~kb}$ upstream of ZNF469 is interesting as bi-allelic mutations in this gene cause Brittle cornea syndrome in which patients have extremely thin and fragile corneas, ${ }^{51}$ however, GWAS showed an unexpected effect direction, with the CCT-increasing allele leading to an increased risk for $\mathrm{KC}$. The authors concluded that these findings demonstrated that part of the genetic predisposition to $\mathrm{KC}$ is mediated through genes underlying CCT, with the remaining predisposition attributable to alternative mechanisms. ${ }^{91}$ This conclusion mirrors the clinical finding that the occurrence of a relatively thin cornea in isolation is distinct from the progressive regional thinning of the cornea that is a feature of KC.

\section{Gene expression studies}

Differences between the expression of genes in normal corneas and corneas with $\mathrm{KC}$ complement the proteomic studies to identify disease pathways. In addition to many focussed studies on particular genes or gene families, other studies have investigated the transcriptome.
Microarray analysis of the KC epithelium compared with controls revealed 56 genes with differential expression, further delineated into genes with a functional role in the cytoskeleton, extracellular matrix, transmembrane signalling, cell-cell interaction, and cell-matrix interaction. The KRT6 gene was the most upregulated gene in this study. ${ }^{92}$ Another study used cultured keratocytes and a specific microarray for apoptosis genes, and concluded that the differentially expressed apoptosis genes identified may have an important role in stromal thinning. ${ }^{93}$ Cultured keratocytes with a fibroblast morphology were also used in a genome-wide transcriptome microarray study, revealing a 212-fold reduction in the mRNA levels of alcohol dehydrogenase (class 1) beta polypeptide (ADH1B). ${ }^{94}$ However, it is currently not clear if ADH1B levels are a marker for, or a potential mediator of, keratoconus. Cultured corneal stromal fibroblasts from normal and KC corneas were used for a PCR based study, that revealed differential expression of eight genes, including TIMP1, TIMP3 and $B M P 4 .{ }^{95} A Q P 5$ which encodes a water channel expressed in the corneal epithelium has been observed to be downregulated in KC corneas compared with controls, ${ }^{96}$ however this finding was not replicated by a subsequent study comparing AQP5 levels in $\mathrm{KC}$ and healthy corneas. ${ }^{97}$ One recent study used pooled patient corneas for microarray transcriptome analysis, and identified 87 differentially expressed genes. ${ }^{98}$ The majority were downregulated, controlled by the transcription factor AP-1.

None of the differentially expressed genes in any of these studies significantly overlap each other, nor do they help validate any of the candidate genes from genetic studies. This is likely due to a combination of the different tissue and cell types used, genetic heterogeneity and the different experimental methods and arrays. They do, however highlight similar pathways of cellular differentiation, proliferation, and apoptosis that correlate with the proteomic data. Such expression analyses are a valuable addition to the other approaches to elucidate the pathogenesis of $\mathrm{KC}$, however further detailed studies are required to tease out primary from secondary effects.

\section{Conclusions}

Different approaches have been used to investigate and define the phenotype, mechanisms and causes of KC. Observations of corneal changes that occur in KC often do not distinguish between primary changes and secondary inflammatory or degenerative effects. Although many differences have been identified that distinguish the $\mathrm{KC}$ cornea from the normal cornea, it has not been possible to trace these changes back to primary causes, or to identify the triggers that precipitate the 
cascade of events that leads to the clinical picture of KC. ${ }^{99}$ Similarly, a range of suggestive genetic loci and variants have been implicated in the genetic susceptibility of $\mathrm{KC}$, however the current lack of large effect contributions of these loci, SNPs and gene variants suggests a complex aetiology or convergence of multiple disease pathways. Extrapolating these data to disease mechanisms is currently problematic but the recent advances in next-generation sequencing technologies promise rapid progress in this field.

\section{Conflict of interest}

The authors declare no conflict of interest.

\section{Acknowledgements}

We thank the Lanvern Foundation, Moorfields Special Trustees and Moorfields Eye Charity, the National Institute for Health Research (NIHR) (Moorfields Eye Hospital and UCL Institute of Ophthalmology (London, UK)), and Rosetrees Trust for financial support. This is a brief review and by no means comprehensive, and we acknowledge that many important studies are not referenced.

\section{References}

1 Krachmer JH, Feder RS, Belin MW. Keratoconus and related noninflammatory corneal thinning disorders. Surv Ophthalmol 1984; 28(4): 293-322.

2 Rabinowitz YS. Keratoconus. Surv Ophthalmol 1998; 42(4): 297-319.

3 Hill AB. The Environment and Disease: Association or Causation? Proc R Soc Med 1965; 58: 295-300

4 Eichler EE, Flint J, Gibson G, Kong A, Leal SM, Moore JH et al. Missing heritability and strategies for finding the underlying causes of complex disease. Nat Rev Genet 2010; 11(6): 446-450.

5 Teng CC. Electron microscope study of the pathology of keratoconus: part 1. Am J Ophthalmol 1963; 55: 18-47.

6 Tsubota K, Mashima Y, Murata H, Sato N, Ogata T. Corneal epithelium in keratoconus. Cornea 1995; 14(1): 77-83.

7 Sawaguchi S, Fukuchi T, Abe H, Kaiya T, Sugar J, Yue BY. Three dimensional electron microscopic study of keratoconus. Arch Ophthalmol 1998; 116: 62-98.

8 Sturbaum CW, Peiffer Jr RL. Pathology of corneal endothelium in keratoconus. Ophthalmologica 1993; 206(4): 192-208.

9 Critchfield J, Caladra A, Nesburn A, Kenney M, Keratoconus. I. Biomechanical studies of normal and keratoconus cornea. Exp Eye Res 1988; 46: 953-963.

10 Buddecke E, Wollensak J. Acid mucopolysaccharide and glycoprotein in the human cornea in relation to age and keratoconus. Albrecvht von Graefes Arch Klin Exp Ophthalomol 1966; 172: 105-120.

11 Sawaguchi S, Twining SS, Yue BY, Chang SH, Zhou X, Loushin $\mathrm{G}$ et al. Alpha-2-Macro-globulin levels in normal and keratoconus corneas. Invest Ophthalmol Vis Sci 1994; 35: 4008-4014.

12 Funderburgh JL, Hevelone ND, Roth MR, Funderburgh ML, Rodrigues M, Nirankari VS et al. Decorin and biglycan of normal and pathological human corneas. Invest Ophthalmol Vis Sci 1998; 39(10): 1957-1964.

13 Joseph R, Srivastava O, Pfister R. Differential epithelial and stromal protein profiles in keratoconus and normal human corneas. Exp Eye Res 2011; 92: 282-298.

14 Wentz-Hunter K, Cheng EL, Ueda J, Sugar J, Yue BYGT. Keratocan expression is increased in the stroma of keratoconus corneas. Mol Med 2001; 7(7): 470-477.

15 Funderburgh JL, Panjwani N, Conrad GW, Baum J. Altered keratan sulphate epitopes in keratoconus. Invest Ophthalmol Vis Sci 1989; 30(10): 2278-2281.

16 Zimmermann DR, Fischer RW, Winterhalter KH, Witmer R, Vaughan L. Comparative studies of collagens in normal and keratoconus corneas. Exp Eye Res 1998; 46(3): 431-442.

17 Nakayasu K, Tanaka M, Konomi H, Hayashi S. Distribution of types I, II, II, IV and V collagen in normal and keratoconus corneas. Ophthalmic Res 1986; 18: 1-10.

18 Newsome DA, Foidart JM, Hassell JR, Krachmer JH, Rodrigues M, Katz SI. Detection of specific collagen types in normal and keratoconus corneas. Invest Ophthalmol Vis Sci 1981; 20: 738-750.

19 Hayes S, Boote C, Tuft S, Quantock A, Meek K. A study of corneal thickness, shape and collagen organisation in keratoconus using videokeratography and X-ray scattering techniques. Exp Eye Res 2007; 84(3): 423-434.

20 Oxlund H, Simonsen AH. Biochemical studies of normal and keratoconus corneas. Acta Ophthalmologica 1985; 63(6): 666-669.

21 Zhou L, Zhao SZ, Koh SK, Chen L, Vaz C, Tanavde V et al. In-depth analysis of the human tear proteome. J Proteomics 2012; 75(13): 3877-3885.

22 Lema I, Sobrino T, Duran JA, Brea D, Diez-Feijoo E. Subclinical keratoconus and inflammatory molecules from tears. Br J Ophthalmol 2009; 93(6): 820-824.

23 Jun AS, Cope L, Speck C, Feng X, Lee S, Meng H et al. Subnormal cytokine profile in the tear fluid of keratoconus patients. PLoS One 2011; 6(1): e16437.

24 Joseph R, Srivastava OP, Pfister RR. Differential epithelial and stromal protein profiles in keratoconus and normal human corneas. Exp Eye Res 2011; 92(4): 282-298.

25 Chaerkady R, Shao H, Scott SG, Pandey A, Jun AS, Chakravarti S. The keratoconus corneal proteome: loss of epithelial integrity and stromal degeneration. J Proteomics 2013; 87: 122-131.

26 Edmund C. Corneal elasticity and ocular rigidity in normal and keratoconic eyes. Acta Ophthalmol (Copenh) 1988; 66(2): 134-140.

27 Tuft SJ, Fitzke FW, Buckley RJ. Myopia following penetrating keratoplasty for keratoconus. $\mathrm{Br}$ J Ophthalmol 1992; 76(11): 642-645.

28 Patey A, Savoldelli M, Pouliquen Y. Keratoconus and normal cornea: A comparative study of collagenous fibers of the corneal stroma by image analysis. Cornea 1984; 3 : 119-124.

29 Fullwood NJ, Tuft SJ, Malik NS, Meek KM, Ridgway AEA, Harrison RJ. Synchrotron x-ray diffraction studies of keratoconus corneal stroma. Invest Ophthalmol Vis Sci 1992; 33(5): 1734-1741.

30 Kenney M, Chwa M, Opbroek AJ, Brown DJ. Increased gelatinolytic activity in keratoconus cultures. A correlation 
to an altered matrix metalloproteinase-2/tissue inhibitor of metalloproteinase ratio. Cornea 1994; 13(2): 114-124.

31 Sherwin T, Brookes NH, Loh IP, Poole CA, Clover GM. Cellular incursion into Bowman's membrane in the peripheral cone of the keratoconic cornea. Exp Eye Res 2002; 74(4): 473-482.

32 Zhou LL, Sawaguchi S, Twining SS, Sugar J, Feder RS, Yue BY. Expression of degradative enzymes and protease inhibitors in corneas with keratoconus. Invest Ophthalmol Vis Sci 1998; 39: 1117-1124.

33 Polack FM. Contributions of electron microscopy to the study of corneal pathology. Surv Ophthalmol 1976; 20: 375-414.

34 Bron AJ. Keratoconus. Cornea 1988; 7(3): 163-169.

35 Morshige N, Wahlert A, Kenney M, Brown D, Kawamoto K, Chikama T et al. Second harmonic imaging microscopy of normal and keratoconus cornea. Invest Ophthalmol Vis Sci 2007; 48(3): 1087-1094.

36 Radner W, Zehetmayer M, Skorpik C, Mallinger R. Altered organization of collagen in the apex of keratoconus corneas. Ophthalmic Res 1998; 30(5): 327-332.

37 Abahussin M, Hayes S, Knox Cartwright N, Kamma-Lorger C, Khan Y, Marshall J et al. 3D collagen orientation study in human cornea using $x$-ray diffraction and femtosecond laser technology. Invest Ophthalmol Vis Sci 2009; 50(11): 5159-5164.

38 Meek K, Blamires T, Elliot G, Gyi TJ, Nave C. The organisation of collagen fibrils in the human corneal stroma: a synchrotron x-ray diffraction study. Curr Eye Res 1987; 6(7): 841-846.

39 Meek KM, Tuft SJ, Huang Y, Gill PS, Hayes S, Newton RH et al. Changes in collagen orientation and distribution in keratoconus corneas. Invest Ophthalmol Vis Sci 2005; 46(6): 1948-1956.

40 Daxer A, Fratzl P. Collagen fibril orientation in the human corneal stroma and its implications in keratoconus. Invest Ophthalmol Vis Sci 1997; 38: 121-129.

41 Hayes S, Kamma-Lorger C, Boote C, Young R, Quantock A, Rost A et al. The effect of riboflavin/UVA collagen cross-linking therapy on the structure and hydrodynamic behaviour of the ungulate and rabbit corneal stroma. PLoS One 2013; 8(1): e52860.

42 Millodot M, Shneor E, Albou S, Atlani E, Gordon-Shaag A. Prevalence and associated factors of keratoconus in Jerusalem: a cross-sectional study. Ophthalmic Epidemiol 2011; 18(2): 91-97.

43 Gorskova EN, Sevost'ianov EN. [Epidemiology of keratoconus in the Urals]. Vestn Oftalmol 1998; 114(4): 38-40.

44 Georgiou T, Funnell CL, Cassels-Brown A, O'Conor R. Influence of ethnic origin on the incidence of keratoconus and associated atopic disease in Asians and white patients. Eye (Lond) 2004; 18(4): 379-383.

45 Pearson AR, Soneji B, Sarvananthan N, Sandford-Smith JH. Does ethnic origin influence the incidence or severity of keratoconus? Eye (Lond) 2000; 14(Pt 4): 625-628

46 Szczotka-Flynn L, Slaughter M, McMahon T, Barr J Edrington T, Fink B et al. Disease severity and family history in keratoconus. Br J Ophthalmol 2008; 92(8): 1108-1111.

47 Wang Y, Rabinowitz YS, Rotter JI, Yang H. Genetic epidemiological study of keratoconus: evidence for major gene determination. Am J Med Genet 2000; 93(5): 403-409.

48 Tuft SJ, Hassan H, George S, Frazer DG, Willoughby CE, Liskova P. Keratoconus in 18 pairs of twins. Acta Ophthalmol 2012; 90(6): e482-e486.
49 McMahon TT, Kim LS, Fishman GA, Stone EM, Zhao XC, Yee RW et al. CRB1 gene mutations are associated with keratoconus in patients with leber congenital amaurosis. Invest Ophthalmol Vis Sci 2009; 50(7): 3185-3187.

50 Hughes AE, Bradley DT, Campbell M, Lechner J, Dash DP, Simpson DA et al. Mutation altering the miR-184 seed region causes familial keratoconus with cataract. Am J Hum Genet 2011; 89(5): 628-633.

51 Abu A, Frydman M, Marek D, Pras E, Nir U, Reznik-Wolf H et al. Deleterious mutations in the Zinc-finger 469 gene cause brittle cornea syndrome. Am J Hum Genet 2008; 82(5): 1217-1222.

52 Burkitt Wright EM, Spencer HL, Daly SB, Manson FD, Zeef LA, Urquhart J et al. Mutations in PRDM5 in brittle cornea syndrome identify a pathway regulating extracellular matrix development and maintenance. Am J Hum Genet 2011; 88(6): 767-777.

53 Shapiro BL. Down syndrome and associated congenital malformations. J Neural Transm Suppl 2003; 67: 207-214.

54 Cullen JF, Butler HG. Mongolism (Down's syndrome) and keratoconus. Br J Ophthalmol 1963; 47: 321-330.

55 Robertson I. Keratoconus and the Ehlers-Danlos syndrome: a new aspect of keratoconus. Med J Aust 1975; 1(18): 571-573.

56 Woodward EG, Morris MT. Joint hypermobility in keratoconus. Ophthalmic Physiol Opt 1990; 10(4): 360-362.

57 Wojcik KA, Kaminska A, Blasiak J, Szaflik J, Szaflik JP. Oxidative stress in the pathogenesis of keratoconus and fuchs endothelial corneal dystrophy. Int J Mol Sci 2013; 14(9): 19294-19308.

58 Udar N, Atilano SR, Brown DJ, Holguin B, Small K, Nesburn AB et al. SOD1: a candidate gene for keratoconus. Invest Ophthalmol Vis Sci 2006; 47(8): 3345-3351.

59 Stabuc-Silih M, Strazisar M, Hawlina M, Glavac D. Absence of pathogenic mutations in VSX1 and SOD1 genes in patients with keratoconus. Cornea 2010; 29(2): 172-176.

60 Saee-Rad S, Hashemi H, Miraftab M, Noori-Daloii MR, Chaleshtori MH, Raoofian R et al. Mutation analysis of VSX1 and SOD1 in Iranian patients with keratoconus. Mol Vis 2011; 17: 3128-3136.

61 Heon E, Greenberg A, Kopp KK, Rootman D, Vincent AL, Billingsley G et al. VSX1: a gene for posterior polymorphous dystrophy and keratoconus. Hum Mol Genet 2002; 11(9): 1029-1036.

62 Bisceglia L, Ciaschetti M, De Bonis P, Campo PA, Pizzicoli C, Scala C et al. VSX1 mutational analysis in a series of Italian patients affected by keratoconus: detection of a novel mutation. Invest Ophthalmol Vis Sci 2005; 46(1): 39-45.

63 Aldave AJ, Yellore VS, Salem AK, Yoo GL, Rayner SA, Yang $\mathrm{H}$ et al. No VSX1 gene mutations associated with keratoconus. Invest Ophthalmol Vis Sci 2006; 47(7): 2820-2822.

64 Liskova P, Ebenezer ND, Hysi PG, Gwilliam R, El-Ashry MF, Moodaley LC et al. Molecular analysis of the VSX1 gene in familial keratoconus. Mol Vis 2007; 13: 1887-1891.

65 De Bonis P, Laborante A, Pizzicoli C, Stallone R, Barbano R, Longo $C$ et al. Mutational screening of VSX1, SPARC, SOD1, LOX, and TIMP3 in keratoconus. Mol Vis 2011; 17: 2482-2494.

66 Guan T, Liu C, Ma Z, Ding S. The point mutation and polymorphism in keratoconus candidate gene TGFBI in Chinese population. Gene 2012; 503(1): 137-139.

67 Klintworth GK. Corneal dystrophies. Orphanet J Rare Dis 2009; $4: 7$. 
68 Lechner J, Dash DP, Muszynska D, Hosseini M, Segev F, George $\mathrm{S}$ et al. Mutational spectrum of the ZEB1 gene in corneal dystrophies supports a genotype-phenotype correlation. Invest Ophthalmol Vis Sci 2013; 54(5): 3215-3223.

69 Droitcourt C, Touboul D, Ged C, Ezzedine K, Cario-Andre $\mathrm{M}$, de Verneuil $\mathrm{H}$ et al. A prospective study of filaggrin null mutations in keratoconus patients with or without atopic disorders. Dermatology 2011; 222(4): 336-341.

70 Aldave AJ, Bourla N, Yellore VS, Rayner SA, Khan MA, Salem AK et al. Keratoconus is not associated with mutations in COL8A1 and COL8A2. Cornea 2007; 26(8): 963-965.

71 Karolak JA, Kulinska K, Nowak DM, Pitarque JA, Molinari A, Rydzanicz $\mathrm{M}$ et al. Sequence variants in COL4A1 and COL4A2 genes in Ecuadorian families with keratoconus. Mol Vis 2011; 17: 827-843.

72 Aldahmesh MA, Khan AO, Alkuraya H, Adly N, Anazi S, Al-Saleh AA et al. Mutations in LRPAP1 are associated with severe myopia in humans. Am J Hum Genet 2013; 93(2): 313-320.

73 Al-Mayouf SM, Sunker A, Abdwani R, Abrawi SA, Almurshedi F, Alhashmi N et al. Loss-of-function variant in DNASE1L3 causes a familial form of systemic lupus erythematosus. Nat Genet 2011; 43(12): 1186-1188.

74 Wheeler J, Hauser MA, Afshari NA, Allingham RR, Liu Y. The genetics of keratoconus: a review. Reproductive Sys Sexual Disord 2012; S6: 001. doi:10.4172/2161-038X.S6-001.

75 Bisceglia L, De Bonis P, Pizzicoli C, Fischetti L, Laborante A, Di Perna $\mathrm{M}$ et al. Linkage analysis in keratoconus: replication of locus $5 \mathrm{q} 21.2$ and identification of other suggestive loci. Invest Ophthalmol Vis Sci 2009; 50(3): 1081-1086.

76 Tang YG, Rabinowitz YS, Taylor KD, Li X, Hu M, Picornell Y et al. Genomewide linkage scan in a multigeneration Caucasian pedigree identifies a novel locus for keratoconus on chromosome 5q14.3-q21.1. Genet Med 2005; 7(6): 397-405.

77 Li X, Rabinowitz YS, Tang YG, Picornell Y, Taylor KD, Hu M et al. Two-stage genome-wide linkage scan in keratoconus sib pair families. Invest Ophthalmol Vis Sci 2006; 47(9): 3791-3795.

78 Czugala M, Karolak JA, Nowak DM, Polakowski P, Pitarque J, Molinari A et al. Novel mutation and three other sequence variants segregating with phenotype at keratoconus 13q32 susceptibility locus. Eur J Hum Genet 2012; 20(4): 389-397.

79 Altshuler D, Daly MJ, Lander ES. Genetic mapping in human disease. Science 2008; 322(5903): 881-888.

80 Tenkman LR, Price MO, Price Jr., FW. Keratoconus onset after age 50. J Refract Surg 2012; 28(6): 436-438.

81 Koboldt DC, Steinberg KM, Larson DE, Wilson RK, Mardis ER. The next-generation sequencing revolution and its impact on genomics. Cell 2013; 155(1): 27-38.

82 Iliff BW, Riazuddin SA, Gottsch JD. A single-base substitution in the seed region of miR-184 causes EDICT syndrome. Invest Ophthalmol Vis Sci 2012; 53(1): 348-353.

83 Iliff BW, Riazuddin SA, Gottsch JD. Documenting the corneal phenotype associated with the MIR184 c.57C $>$ T mutation. Am J Hum Genet 2012; 90(5): 934; author reply 934-935.

84 Lechner J, Bae HA, Guduric-Fuchs J, Rice A, Govindarajan $\mathrm{G}$, Siddiqui $\mathrm{S}$ et al. Mutational analysis of MIR184 in sporadic keratoconus and myopia. Invest Ophthalmol Vis Sci 2013; 54(8): 5266-5272.

85 McCarthy MI, Abecasis GR, Cardon LR, Goldstein DB, Little J, Ioannidis JP et al. Genome-wide association studies for complex traits: consensus, uncertainty and challenges. Nat Rev Genet 2008; 9(5): 356-369.

86 Burdon KP, Macgregor S, Bykhovskaya Y, Javadiyan S, Li X, Laurie $\mathrm{KJ}$ et al. Association of polymorphisms in the hepatocyte growth factor gene promoter with keratoconus. Invest Ophthalmol Vis Sci 2011; 52(11): 8514-8519.

87 Li X, Bykhovskaya Y, Haritunians T, Siscovick D, Aldave A, Szczotka-Flynn L et al. A genome-wide association study identifies a potential novel gene locus for keratoconus, one of the commonest causes for corneal transplantation in developed countries. Hum Mol Genet 2012; 21(2): 421-429.

88 Bae HA, Mills RA, Lindsay RG, Phillips T, Coster DJ, Mitchell $\mathrm{P}$ et al. Replication and meta-analysis of candidate loci identified variation at RAB3GAP1 associated with keratoconus. Invest Ophthalmol Vis Sci 2013; 54(7): 5132-5135.

89 Dimasi DP, Burdon KP, Craig JE. The genetics of central corneal thickness. Br J Ophthalmol 2010; 94(8): 971-976.

90 Gordon MO, Beiser JA, Brandt JD, Heuer DK, Higginbotham EJ, Johnson CA et al. The Ocular Hypertension Treatment Study: baseline factors that predict the onset of primary open-angle glaucoma. Arch Ophthalmol 2002; 120(6): 714-720; discussion 829-730.

91 Lu Y, Vitart V, Burdon KP, Khor CC, Bykhovskaya Y, Mirshahi A et al. Genome-wide association analyses identify multiple loci associated with central corneal thickness and keratoconus. Nat Genet 2013; 45(2): 155-163.

92 Nielsen K, Birkenkamp-Demtroder K, Ehlers N, Orntoft TF. Identification of differentially expressed genes in keratoconus epithelium analyzed on microarrays. Invest Ophthalmol Vis Sci 2003; 44(6): 2466-2476.

93 Ha NT, Nakayasu K, Murakami A, Ishidoh K, Kanai A. Microarray analysis identified differentially expressed genes in keratocytes from keratoconus patients. Curr Eye Res 2004; 28(6): 373-379.

94 Mootha VV, Kanoff JM, Shankardas J, Dimitrijevich S. Marked reduction of alcohol dehydrogenase in keratoconus corneal fibroblasts. Mol Vis 2009; 15: 706-712.

95 Lee JE, Oum BS, Choi HY, Lee SU, Lee JS. Evaluation of differentially expressed genes identified in keratoconus. Mol Vis 2009; 15: 2480-2487.

96 Rabinowitz YS, Dong L, Wistow G. Gene expression profile studies of human keratoconus cornea for NEIBank: a novel cornea-expressed gene and the absence of transcripts for aquaporin 5. Invest Ophthalmol Vis Sci 2005; 46(4): 1239-1246.

97 Garfias Y, Navas A, Perez-Cano HJ, Quevedo J, Villalvazo L, Zenteno JC. Comparative expression analysis of aquaporin5 (AQP5) in keratoconic and healthy corneas. Mol Vis 2008; 14: $756-761$.

98 Mace M, Galiacy SD, Erraud A, Mejia JE, Etchevers H, Allouche $\mathrm{M}$ et al. Comparative transcriptome and network biology analyses demonstrate antiproliferative and hyperapoptotic phenotypes in human keratoconus corneas. Invest Ophthalmol Vis Sci 2011; 52(9): 6181-6191.

99 Cristina Kenney M, Brown DJ. The cascade hypothesis of keratoconus. Cont Lens Anterior Eye 2003; 26(3): 139-146. 